\title{
30-year experience of open reduction internal fixation of limb fractures using biodegradable polymeric devices
}

\author{
0. G. Dudko, G. Ye. Dudko
}

HSEE "Bukovinian State Medical University", Chernivtsi, Ukraine

Key words: fracture fixation, outcome assessment, biodegradable polymeric devices, polyglycolic acid (PGA), polylactic acid (PLA).

\section{Zaporozhye} medical journal 2018; 20 (4), 562-567

Dol:

10.14739/2310-1210

2018.4.135555

E-mail:

dudko.oleksii@

bsmu.edu.ua

Ключові слова: остеосинтез переломів, відалеені результати, біодеградуючі фіксатори, полігліколіА, полікактин.

Запорізький медичний журнал. - 2018. T. 20, № 4(109). C. 562-567
The accumulated clinical experience of biodegradable polymeric device's application within 30 years made it possible to undertake a systematic research that would cover not only the immediate outcomes, but also the long-term results of these orthopedic surgeries.

Objective. The present study was conducted to estimate long-term clinical and radiological outcomes, to identify possible adverse reactions or side-effects that might stem from the implanted biodegradable materials or from the products of their biodegradation.

Materials and methods. The study involved 41 patients that had intra- or periarticular fractures of limbs and were operated using biodegradable devices with the follow-up period spanning from 1 to 27 years. In 37 cases domestically manufactured pins and screws made of polyglycolide (PGA) were used and in 4 cases - polylactide-polyglycolide (PLA/PGA) devices. The results were compared with metal osteosynthesis. Our modification of National Score System was used to estimate clinical and radiological (X-ray, computed tomography (CT), magnetic resonance imaging (MRI)) results.

Results. The long-term clinical and radiological follow-up after internal fixation with PGA bone fracture fixation devices (BFFDs) revealed the higher score in patients with humeral condyles fractures $(19.8 \pm 0.6)$ and malleolus fractures $(19.7 \pm 0.5)$ compared with the control group of patients, who underwent internal fixation with metal devices $-18.0 \pm 0.9$ and $17.1 \pm 0.8$, respectively $(P>0.05)$. The similar results were revealed for PGA/PLA group with shorter follow-up period (from 1 to 3 years, $P>0.05$ ).

Conclusions. The early post-operative complications rate after polymeric osteosynthesis and metal osteosynthesis turned out to be similar, and there were no signs of its dependence on the kind of substance the device was made of. The second surgical intervention to remove metal devices affected the long-term follow-up results in this group. Bone structure in the places of PGA implantation was completely restored in operated patients. Further wide-ranging trials of various biodegradable fixation devices should be performed to determinate the preferable materials depending on the peculiarities of fracture site.

\section{0-річний досвід застосування біодеградуючих полімерних фіксаторів Аля оперативного мікування переломів кінцівок}

\section{О. Г. АуАКо, Г. Є. АуАКо}

30-річний досвід клінічного застосування біодеградуючих полімерних фіксаторів дав можливість дослідити та систематизувати не тільки ранні, але й віддалені результати таких оперативних втручань.

Мета роботи - оцінити довготривалі клінічні, радіологічні результати лікування, виявити можливі побічні чи небажані реакції на імплантацію біодеградуючих полімерних матеріалів чи продуктів їх розпаду.

Матеріали та методи. У дослідження включили 41 пацієнта з внутрішньо- та білясуглобовими переломами кінцівок. Хворих оперували біодеградуючими фіксаторами, термін спостереження - від 1 до 27 років. У 37 випадках застосували штифти і гвинти, виготовлені з вітчизняного полігліколіду, в 4 випадках - з сополімеру полілактиду-полігліколіду. Порівнювали з результатами лікування після металоостеосинтезу. Для оцінювання клінічних і радіологічних результатів (рентгенографії, комп'ютерної, магнітно-резонансної томографії) застосовували власну модифікацію національного «Положення про оцінювання наслідків лікування переломів».

Результати. Клінічні, рентгенологічні спостереження у віддалені терміни після остеосинтезу з застосуванням полігліколіду виявили кращі показники в пацієнтів з переломами виростків плечової кістки $(19,8 \pm 0,6)$ та кісток гомілки $(19,7 \pm 0,5)$ порівняно з контрольною групою хворих після металоостеосинтезу - 18,0 $\pm 0,9$ та 17,1 $\pm 0,8$ відповідно ( $p>0,05)$. Схожі результати отримали в групі пацієнтів, яким застосовували полігліколід-полілактидні фіксатори, з меншим терміном спостереження (від 1 до 3 років, $p>0,05$ ).

Висновки. Рівень ранніх післяопераційних ускладнень після полімерного остеосинтезу та металоостеосинтезу був однаковим і вірогідно не залежав від матеріалу, з якого виготовляли фіксатори. Необхідність у повторному хірургічному втручанні для видалення металоконструкції негативно вплинула на наслідки лікування пацієнтів цієї групи у віддалені терміни. У хворих, які оперовані фіксаторами з полігліколіду, визначили повне відновлення кісткової структури в ділянці його імплантації. Широкомасштабні дослідження різних біодеградуючих фіксаторів дадуть змогу визначити критерії вибору певного матеріалу залежно від особливостей ділянки перелому.

Ключевые слова: остеосинтез переломов, отАаленные результаты, биодеградирующие фиксаторы, ПОлиглиКОЛиА, поликактин.

\section{0-летний опыт использования биодеградирующих полимерных фиксаторов Аля оперативного лечения переломов конечностей}

\section{О. Г. Ауако, Г. Е. Аудко}

Накопленный 30-летний опыт клинического использования биодеградирующих полимерных фиксаторов позволил исследовать и систематизировать не только ранние, но и поздние результаты таких оперативных вмешательств. 
Цель работы - провести оценку длительных клинических и радиологических результатов лечения, установить возможные побочные или нежелательные реакции на имплантацию биодеградирующих полимерных материалов или продуктов их распада.

Материалы и методы. Исследование включало 41 пациента с внутри- и околосуставными переломами конечностей, которые были оперированы биодеградирующими фиксаторами, срок наблюдения - от 1 до 27 лет. В 37 случаях использованы штифты и винты, изготовленные из отечественного полигликолида, в 4 случаях - из сополимера полилактид-полигликолида. Сравнение проведено с результатами металлоостеосинтеза. Для оценки клинических и радиологических результатов (рентгенографии, компьютерной и магнитно-резонансной томографии) использовали собственную модификацию национального «Положения про оценку исходов лечения переломов».

Результаты. Клинические и рентгенологические наблюдения в отдаленные сроки после остеосинтеза с использованием полигликолида выявили лучшие показатели у пациентов с переломами отростков плечевой кости $(19,8 \pm 0,6)$ и лодыжек $(19,7 \pm 0,5)$ по сравнению с контрольной группой пациентов после металлоостеосинтеза - 18,0 \pm 0,9 и 17,1 \pm 0,8 соответственно ( $>$ > 0,05). Похожие результаты получены в группе пациентов, у которых использовали полигликолид-полилактидные фиксаторы, с меньшими сроками наблюдения (от 1 до 3 лет, р > 0,05).

Выводы. Уровень ранних послеоперационных осложнений после полимерного остеосинтеза и металлоостеосинтеза не отличался и достоверно не зависел от материала, из которого изготовлены фиксаторы. Необходимость в повторном хирургическом вмешательстве для удаления металлоконструкции негативно повлияла на исходы лечения в данной группе в отдаленные сроки. У больных, оперированных фиксаторами из полигликолида, отмечено полное восстановление костной структуры в месте его имплантации. Проведение дальнейших широкомасштабных исследований различных биодеградирующих фиксаторов позволит определить критерии выбора подходящего материала для остеосинтеза в зависимости от особенностей локализации перелома.

An open reduction internal fixation (ORIF) of limb fractures is a common orthopedic surgical procedure to treat displaced bone limb fractures that is a subject of continuous studies to improve its outcome. ORIF involves the implantation of metal bone fracture fixation device (BFFD) and often is followed by a second surgery aimed to remove the fixator. $A$ great advance in the development of BFFD design for each segment of a bone, which began 3 decades ago, resulted in the availability of various screws, anatomically shaped plates, low contact plates, locking compression plates for each fracture location. Metal BFFDs were improved dramatically, when the manufacturers started to produce them from bioinert titanium and titanium alloys. On the other hand, the metal BFFDs have been demonstrating serious disadvantages, which nobody seems to pay attention to, if not by an accident [1]. The flaws of metal BFFDs include:

- Risks and expenses associated with the second surgery;

- Shielding effect on the bone tissue due to more rigid material of metal bone fixation device;

- Unpleasant feelings in the place of metal device implantation, further aggravated by psychological discomfort related with the presence of a foreign body in limb that the patients suffer from for many years;

- Procedure for removal of metal BFFD can be quite destructive. Some studies revealed clinical cases, when screws or their parts had to be left inside because of the technical difficulties [2].

These facts provided reasons for the continuing search for alternative methods of bone fracture surgical treatment that has been conducting worldwide and particularly in Ukraine. Using BFFDs with biodegradable properties seems to be able to offer a reasonable alternative that could eliminate a problem of a foreign body implantation, since after the fracture healing the biodegradable BFFD is absorbed by the surrounding tissues [3]. Various polymeric devices made from polyglycolide (PGA), polylactic acid (PLA), polydiaxonone etc., are considered to be the most promising [4]. Biodegradable metallic BFFDs, made of magnesium alloys, have much to promise either $[5,6]$. There is a long way to introduce a BFFD, made of a new material, into regular clinical practice. Its stages include biomechanical testing, research, aimed to determine the biodegradation period in vitro and in vivo, study of the surrounding tissues response to the implantation of synthetic material with the tests first run on laboratory animals and then on human body. Next step is to study long-term results of surgeries with implantation of biodegradable BFFDs to check for any possible adverse reactions or side-effects, caused by the implanted material or by products of its biodegradation. So the current study was held to check the safety of biodegradable BFFDs application in long-term outcome before introduction them into wide clinical practice.

\section{Objective}

The present study was conducted to estimate long-term clinical and radiological outcomes, to identify possible adverse reactions or side-effects that might stem from the implanted biodegradable materials or from the products of their degradation.

\section{Materials and methods}

Patients that were involved into the study had intra- or periarticular fractures of upper and lower limbs in $74.7 \%$ cases (Table 1). There were three groups of patients involved in the study - PGA group included 37 patients (9 women, 28 men; women to men ratio - 1:3.1) in age from 31 to 76 (mean age $44.60 \pm 10.79$ ) where results were followed-up from 1 to 27 years (mean $16.30 \pm 6.76$ ). The second group included 4 patients operated with PGA/PLA BFFDs ( 3 women, 1 man) in age from 31 to 50 years (mean age $39.0 \pm 8.2$ ) with results that were followed-up for 1-3 years (mean $2.12 \pm 0.85$ ). The control group included 54 patients (women to men ratio 1:1.18) who underwent metal ORIF, aged from 22 to 81 years (mean $49.6 \pm 9.8$ ), and were followed-up for 1-30 years (mean $11.90 \pm 5.28$ ).

Devices. Biodegradable devices that were used for fracture fixation included pins and screws of domestically manufactured PGA, as well as screws and pins made of
Запорожский медицинский журнал. - 2018. T. 20, № 4(109). C. 562-567 
Table 1. Radiological examination of the patients in the late postoperative period

\begin{tabular}{|c|c|c|c|c|c|c|c|}
\hline \multirow[t]{2}{*}{ № } & \multirow[t]{2}{*}{ Fracture location } & \multicolumn{2}{|l|}{ X-ray } & \multicolumn{2}{|l|}{ CT } & \multicolumn{2}{|l|}{ MRI } \\
\hline & & Abs. & $\%$ & Abs. & $\%$ & Abs. & $\%$ \\
\hline & Biodegradable PGA devices & 37 & 38.95 & 10 & 52.63 & 10 & 100 \\
\hline 1. & Humeral condyles and epicondyles fractures & 10 & 10.53 & 2 & 10.53 & 2 & 20 \\
\hline 2. & Olecranon fractures & 4 & 4.21 & 2 & 10.53 & 2 & 20 \\
\hline 3. & Oblique and spiral diaphyseal tibial fractures & 6 & 6.32 & 2 & 10.53 & 3 & 30 \\
\hline 4. & Malleolus fractures & 16 & 16.84 & 4 & 21.05 & 3 & 30 \\
\hline \multirow[t]{2}{*}{5.} & Talus fracture-dislocation & 1 & 1.05 & - & - & - & - \\
\hline & Biodegradable PLA/PGA devices & 4 & 4.21 & 1 & 5.26 & - & - \\
\hline 1. & Proximal tibial fractures & 1 & 1.05 & 1 & 5.26 & - & - \\
\hline 2. & Distal tibial fractures & 1 & 1.05 & 1 & 5.26 & - & - \\
\hline \multirow[t]{2}{*}{3.} & Malleolus fractures & 2 & 2.1 & - & - & - & - \\
\hline & Metal devices & 54 & 56.84 & 8 & 9.30 & - & - \\
\hline 1. & Humeral condyles and epicondyles fractures & 4 & 4.21 & 2 & 10.53 & - & - \\
\hline 2. & Olecranon fractures & 7 & 7.87 & 2 & 10.53 & - & - \\
\hline 3. & Tibial condyle fracture & 5 & 5.26 & & & & \\
\hline 3. & Oblique and spiral diaphyseal tibial fractures & 18 & 18.95 & 2 & 10.53 & - & - \\
\hline \multirow[t]{2}{*}{4.} & Malleolus fractures & 20 & 21.05 & 2 & 10.53 & - & - \\
\hline & Total & 95 & 100 & 19 & 100 & 10 & 100 \\
\hline
\end{tabular}

Table 2. Criteria to evaluate the results of treatment and their score interpretation

\begin{tabular}{|c|c|c|c|}
\hline & \multicolumn{3}{|c|}{ Score interpretation of the criteria } \\
\hline & $\begin{array}{l}\text { Good } \\
\text { (2 points) }\end{array}$ & $\begin{array}{l}\text { Satisfactory } \\
\text { (1 point) }\end{array}$ & $\begin{array}{l}\text { Unsatisfactory } \\
\text { (0 points) }\end{array}$ \\
\hline \multicolumn{4}{|l|}{ Clinical Criteria } \\
\hline Fracture site pain & Absent & Mild & Intensive \\
\hline Limitation of movements & Slight & Moderate & Severe \\
\hline Function & Normal & Decreased & Significantly decreased \\
\hline Presence of deformity & Absent & Mild & Gross \\
\hline Segments shortening & Absent & Not significant & Significant \\
\hline Sensation disorders & Absent & Mild & Significant \\
\hline Muscle strength & Normal & Decreased & Significantly decreased \\
\hline Neurodystrophic disorders & Absent & Not significant & Significant \\
\hline \multicolumn{4}{|l|}{ Radiological Criteria } \\
\hline Pathologically changed bone areas & Absent & Slight & Intensive \\
\hline Osteoarthritis of adjacent joints & Slight & Moderate & Severe \\
\hline Local osteoporosis & Absent & Mild & Intensive \\
\hline
\end{tabular}

polylactide-polyglycolide (PLA/PGA) produced by Bioretec ${ }^{\circledR}$ company (Finland). The control group included patients with fractures that had been operated with similar metal BFFDs - screws and K-wires.

Scales. To estimate the long-term results of fracture treatment we used the National Scale according to the protocols of "Estimating quality of treatment of injuries and disorders of the locomotor system", approved by Ukraine Ministry of Health (order № 41 from 30.03.1994) [7]. To compare the state of bone tissue at the place of fracture radiological methods of examination were performed for both injured and opposite limbs.

The results were graded as good, satisfactory and unsatisfactory, and were transformed into a score system so that "unsatisfactory result" was graded as 0 points, "satisfactory" as 1 point and "good" as 2 points. Later the sum of the points of all clinical and radiological criteria was recorded as a final result. The score from 15 to 22 points was considered as a good result, from 8 to 14 points as a satisfactory result and from 0 to 7 points as unsatisfactory result (Table 2). Statistical analysis was made with the pro- gram Statistica (version 9.0, 2009, StatSoft Inc.). Student's t-test for quantitative variables was used. Results of scores calculation were given as mean \pm standard deviation values in groups for each fracture location. Data of biodegradable BFFD ORIF groups were compared with the control metal ORIF group with the level of statistical significance $P<0.05$.

The results were also compared with the scores indicating the patients' quality of life that was studied and published in our previous papers.

\section{Results}

Initial clinical trial of PGA BFFDs, which involved 48 patients with avulsion, marginal, intraarticular and some shaft fractures, was held in the Traumatology and Orthopedics Department of Bucovinian State Medical University between 1984 and 1990 [8]. Later the production of these devices was stopped due to some reasons of non-medical nature, such as the lack of investigations in medicine and the collapse of the Soviet Union in 1991. Then afterwards orthopaedic surgeries with biodegradable polymeric devices were restarted in 2014, but those were BFFDs made of PLA/ PGA produced by Bioretec ${ }^{\circledR}$ Company (Finland). 4 surgeries were performed in the clinical unit during 2014-2017.

Considering the fact that mechanical properties of polymeric material were lower than of metal, the PGA BFFDs were applied in the areas that were not exposed to significant physical loads. In cases of avulsion and marginal fractures the mechanical properties of polymeric devices turned out to be sufficient. Biodegradable BFFDs that gradually lose their mechanical properties were used in treatment of cancellous bone fractures, which require shorter healing time. In treatment of diaphyseal fractures the PGA BFFDs were used for internal fixation of oblique and spiral tibial fractures with large fracture plane area.

Classical approaches were used for polymeric osteosynthesis of certain fracture locations. The applied surgical technique didn't differ from ordinary procedure, involving a similar metal device. The operative procedure was performed in the following sequence: first, an open reduction of fracture fragments was made, after that they were joined together with a screw or a pin that was introduced in the canal, previously made, using a drill bit or an awl. In cases of screw usage before it's insertion a thread was cut. Then plaster bandage was applied.

In the first year after the surgery patients were scheduled for clinical and radiological examination in the 1st, 3rd, and 6th months. Next examinations took place after the 1st, $3 \mathrm{rd}$ and 5 th years, and in later periods the patients were examined once in 5-10 years.

With the increase of follow-up duration the number of examined patients was gradually decreasing. Some of them were lost from view due to the circumstances of household nature, for example relocation. The others were not able to come in working hours, and individual time of examination had been scheduled for them. Good limb function and absence of complaints in the site of surgery also reduced some patients' wish to come for control examination. On the other hand, some patients wished to get a medical consultation about the problems of musculoskeletal system that were not related to the surgery, like problems with other joints or spine, or a concomitant disease. These were the factors 
that contributed to patients' coming or failing to come for periodical medical examinations.

From 48 patients who underwent internal fixation of bone fractures with PGA devices (screws and pins) only 37 patients ( $77.1 \%$ from the total number) were followed-up and were included in our research. There were 14 patients with fractures of upper limb and 23 patients with fractures of lower limb followed-up for $6-10$ years. 34 patients $(70.8 \%$ from the total number) were examined during the more extended follow-up period spanning 16-20 years. 27 patients $(56.25 \%)$ were examined within $21-25$ years, and 1 patient (2\% from total number) was examined after 27 years of follow-up period.

From 4 patients who underwent bone fractures osteosynthesis with PLA/PGA devices (screws and pins) 1 was followed-up within 3 years, 2 patients - within 2 years, 1 patient - for 1 year.

From PGA device group 5 patients died (13.5\% from total number) in the late postoperative period in age from 60 to 80 years old of the reasons that were not related to the surgeries (acute stroke, coronary heart disease, heart attack, chronic obstructive pulmonary disease, diseases of the gastrointestinal tract etc.). The follow-up of patients results after internal fixation of bone fractures with PGA BFFDs (screws, pins) in the early postoperative period have proved that these devices could safely maintain bone fragments in cases of avulsion fractures, fractures involving the joint and some oblique and spiral shaft fractures. Fixation with screws, polymeric or metal, should be combined with plaster immobilization. Biodegradation of BFFDs took place in parallel with the process of fracture healing. According to the results of roentgenological examinations the fractures were consolidated in optimal terms, if compared with the use of analogous metal devices. Bone defect in the place of implantation was presented as a canal and its regeneration depended on the type and size of a polymeric BFFD and local conditions for its degradation and absorption. After internal fracture fixation with conical biodegradable pins the canal was rebuilt within 6 months, while it took $3-5$ years if the fixation had been done by screws.

The following clinical case illustrates the long-term follow-up of biodegradable BFFD use. Patient V., born in 1961, (case № 1966) was admitted to the clinic 16.02.1986 with the diagnosis: "Closed fractures of medial malleolus, posterior edge of tibia and fracture of fibula in the distal third with foot subluxation". The patient got the injury earlier the same day when he was skiing. After closed reduction and fixation with plaster bandage performing the medial malleolus remained displaced (Fig. 1). On 20.02.1986 open reduction and internal fracture fixation with conical PGA pin was performed. Control X-ray examination proved good position of bone fragments and showed the canal where PGA pin was inserted (Fig. 2).

The injured limb was immobilized by circular plaster bandage for 8 weeks. Postoperative period ran without complications, the wound healed by primary intention. When the patient was examined within 3.5 months, the function of the limb was completely restored, the pain was absent, and the patient could walk with a full weight-bearing. A control X-ray 6 months after the surgery revealed complete restoration of bone structure and pin degradation (Fig. 3). The patient was examined in 2, 10, 22 and 24 years after the surgery (Fig. 4).

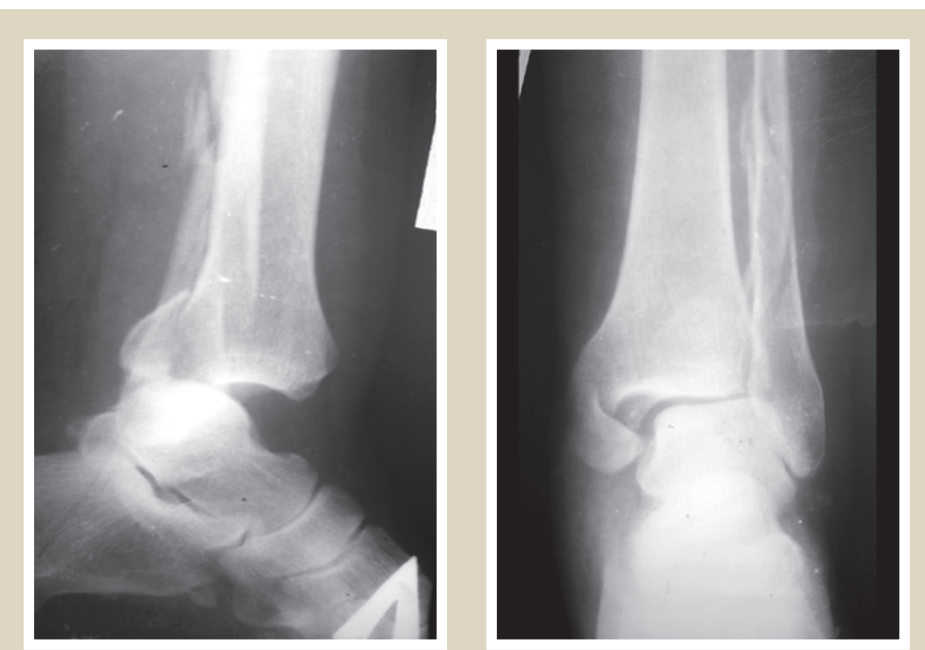

Fig. 1. X-ray of the left ankle joint of patient V., born in 1961 (case № 1966). Closed fractures of medial malleolus, posterior edge of tibia and fracture of fibula in the distal third with lateral-posterior foot subluxation.
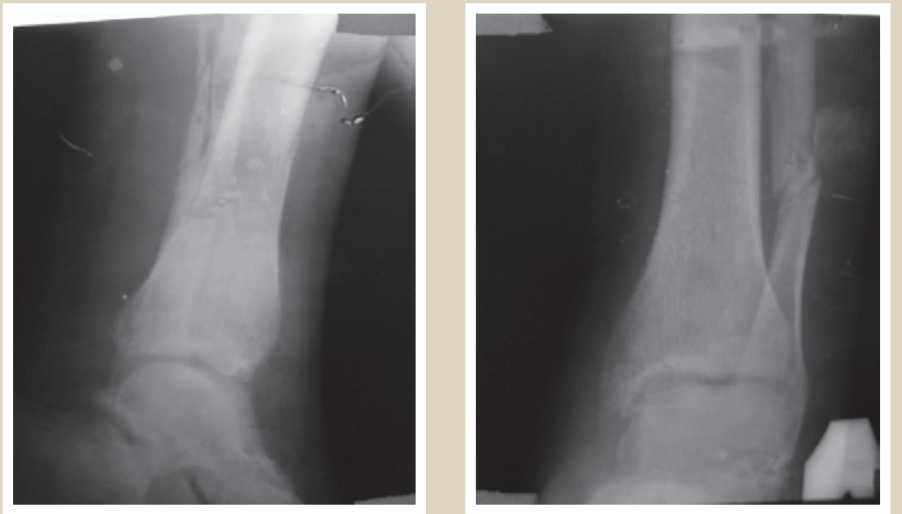

Fig. 2. The same patient. X-ray of the left ankle joint after the polymeric osteosynthesis of medial malleolus with conical PGA pin shows a good position of bone fragments without subluxation.
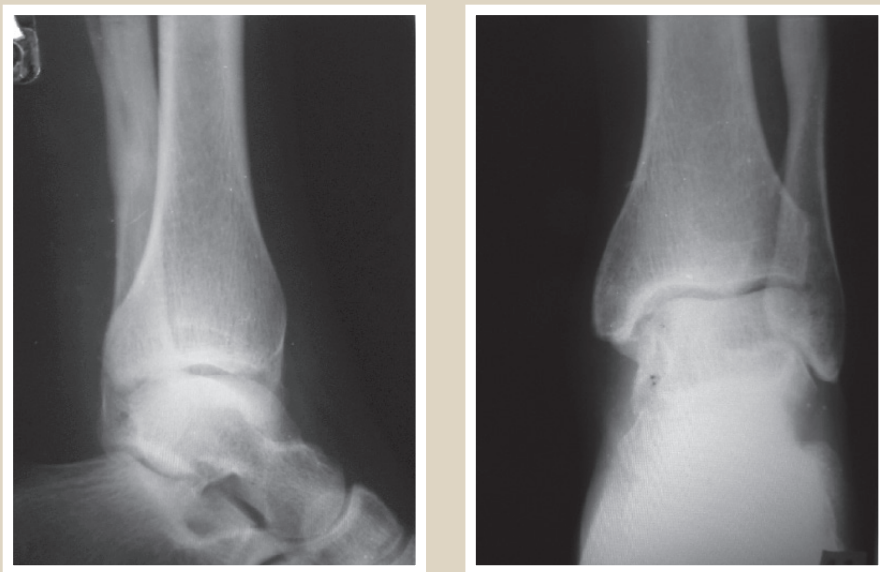

Fig. 3. The same patient. X-ray of the left ankle joint 6 months after the surgery. Complete restoration of bone structure in place of PGA pin implantation.

On control X-rays of both ankle joints from 24.08.2010 the consolidated fractures of left medial and lateral malleolus can be seen. In the place of fracture and the site of polymeric BFFD implantation the bone structure is restored, bone density is the same for both ankle joints (Fig. 4, Fig. 5).

$\mathrm{X}$-rays of the patient $\mathrm{V}$. which were made on the day following the surgery and those which were done 24 years 

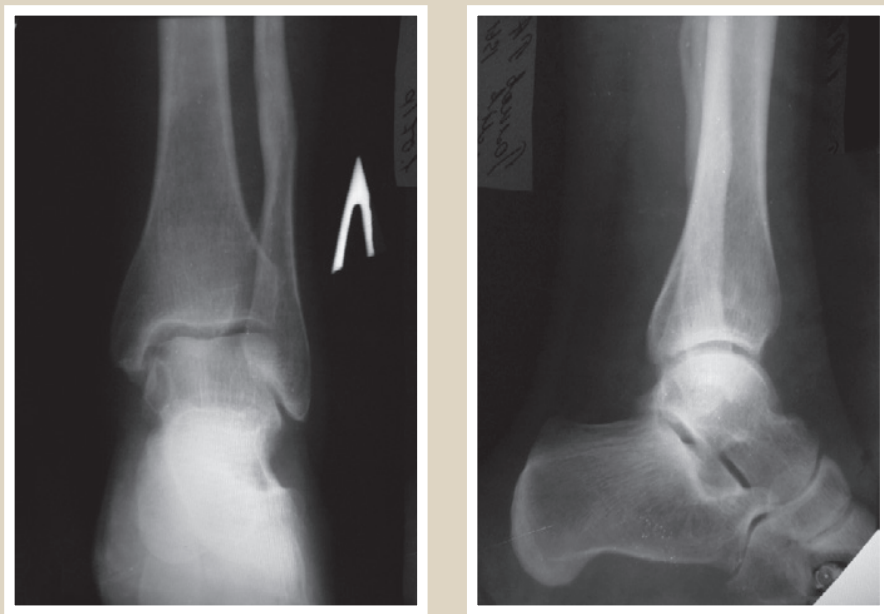

Fig. 4. The same patient. X-ray of the left ankle joint 24 years after polymeric osteosynthesis of the medial malleolus with PGA pin. Bone structure and bone density is similar to the right ankle joint.
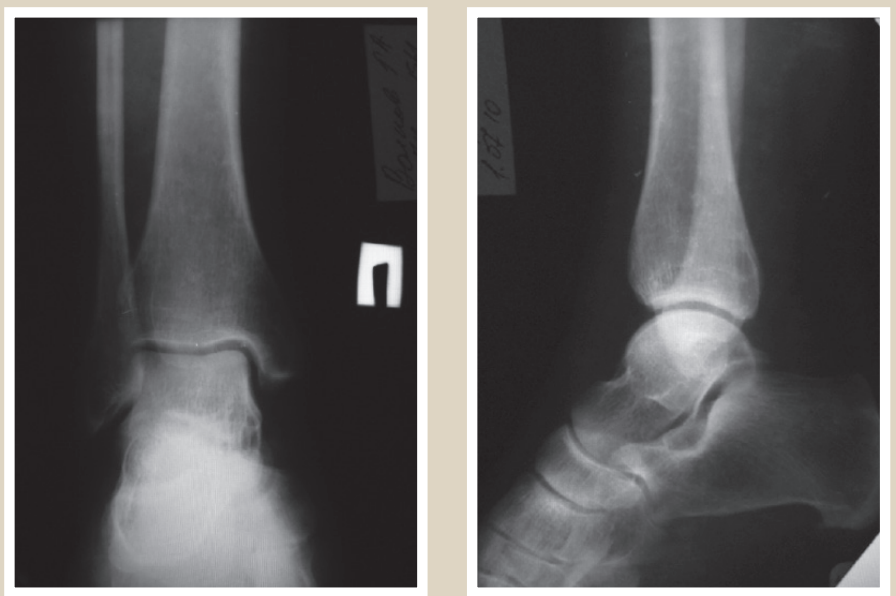

Fig. 5. The same patient. Comparative X-ray of the right ankle joint.
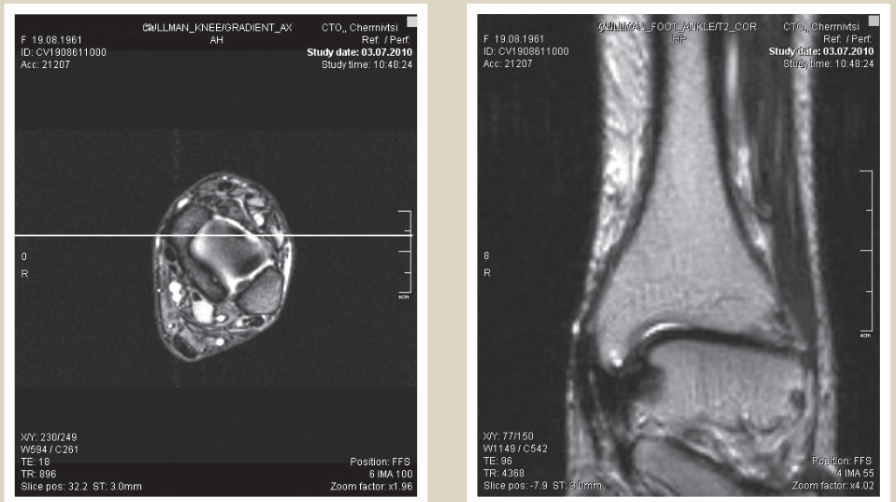

Fig. 6. The same patient. MRI of the left ankle joint 24 years after the polymeric osteosynthesis of medial malleolus with a PGA pin. Pathological changes of bone and soft tissues of the joint were not found. increase. The mortise and joint spaces were equal from both sides. MRI of the ankle joint in axial, coronal and sagittal planes in T1, T2, PD and STIR regimes did not reveal any pathological changes of bone and soft tissues in the areas of medial or lateral malleolus (Fig. 6).

The long term clinical and radiological results of treatment with the use of PGA BFFDs in patients with humeral condyles fractures $(19.8 \pm 0.6)$ and malleolus fractures (19.7 \pm 0.5$)$ were compared with the control group of patients who underwent internal fixation with metal devices $-18.0 \pm 0.9$ and $17.1 \pm 0.8$, respectively $(P>0.05)$. The similar results were revealed for PGA/PLA group with shorter follow-up (from 1 to 3 years, $P>0.05$ ). For olecranon fractures and oblique fractures of tibia the results after PGA use were better too, but statistical significance was lower $(P>0.05)$ due to less number of cases (Table 3 ).

\section{Discussion}

The present clinical trial attempted to compare long-term outcomes of treatment with the use of various biodegradable and metal BFFDs for internal fracture fixation.

The overall short-term results in patients operated with PGA and PLA/PGA BFFDs showed that their mechanical strength was sufficient to immobilize fracture fragments during the period of the healing process, although the external fixation with plaster bandage or brace had been applied. There were no adverse reaction and wound healing problems as well. Though some reports shows aseptic sinus formation that can be related, in our opinion, to the amount of degraded polymeric substances that human organism cannot resolve at once. When small biodegradable devices were used these complications were almost absent. Thus we can assume that other biodegradable polymeric devices, based on polyesters (PLA and copolymers), which are degraded by random hydrolysis in the tricarboxylic acid cycle, are also safe for clinical use. Their products of degradation, water and carbon dioxide, are safe for human organism and excreted from organism through the physiological ways.

The long-term follow-up of the patients, who were operated with PGA BFFDs conducted by means of X-ray within first $10-15$ years and additionally by CT and MRI methods later, revealed complete restoration of bone structure in the place of PGA implantation without pathological formations and other changes that prove high biological compatibility of PGA and normal physiological regeneration of bone tissue in the fracture site and systemically in the patients' organisms as a whole.

The PGA BFFDs which we used in orthopedic surgeries, that provided the background experience for this study, were manufactured according to the experimental technology, developed by the orthopedic surgeons of the Bucovinian State Medical University Clinic. There is no commercial production of such devices in Ukraine so far. Therefore this clinic's orthopedic surgeons have to use PLA/ PGA fixing devices that are available on the market nowadays. Though our experience of PLA/ PGA use is limited to 4 cases and short follow-up time, we have a reason to believe that this and other biodegradable polyesters may also be considered safe for clinical use. 
Table 3. Long-term results of fracture treatment with the use of biodegradable polymeric and metal BFFDs

\begin{tabular}{ll} 
Fracture location & Scores \\
Patients operated with PGA devices, $n=37$ & $19.8 \pm 0.6$ * \\
Humeral condyle fractures, $n=10$ & $18.7 \pm 0.5$ \\
Olecranon fractures, $n=4$ & $18.40 \pm 1.04$ \\
Oblique and spiral tibial diaphyseal fractures, $n=6$ & $19.7 \pm 0.5$ * \\
Malleolus fractures, $n=16$ & 8.0 \\
Talus fracture-dislocation, $n=1$ & \\
Patients operated with PLA/PGA devices, $n=4$ & 19 \\
Tibial condyle fractures, $n=1$ & 18 \\
Oblique, spiral diaphyseal or metaepiphysial tibial fractures, $n=1$ & $18.8 \pm 0.9$ \\
Malleolus fractures, $n=2$ & \\
Patients operated with metal devices, $n=54$ & $18.0 \pm 0.9$ \\
Humeral condyle fractures, $n=4$ & $18.0 \pm 0.6$ \\
Olecranon fractures, $n=7$ & $11.0 \pm 1.3$ \\
Tibial condyle fractures, $n=5$ & $17.8 \pm 0.7$ \\
Oblique and spiral diaphyseal tibial fractures, $n=18$ & $17.1 \pm 0.8$ \\
\hline Malleolus fractures, $n=20$ &
\end{tabular}

*: level of statistical significance $P<0.05$ compared with the control group of patients operated with metal devices; for others results $-P>0.05$.

\section{Conclusions}

The rate of early complications after polymeric osteosynthesis in this clinical trial turned out to be similar to that after metal osteosynthesis. The complications rate was not related to the type of polymeric substance (PGA and PLA/ $P G A)$ that was implanted. The complete restoration of bone structure in the places of PGAimplantation was revealed in a long-term follow-up. For some fracture locations the results were better in the group of biodegradable BFFDs than for metal group, where the second surgical intervention to remove metal devices was required.

Further wide-ranging long-term trials have yet to be performed to guarantee completely safe surgical treatment of fractures with BFFDs made of various novel biodegradable materials.

Prospective studies. We suggest that polymeric material could be improved in such a way that its degradation would pass uniformly and regulated by a technological process according to certain bone fracture location and healing time.

Conflicts of Interest: authors have no conflict of interest to declare. Конфмікт інтересів: віАсутній.

Information about authors:

Dudko 0. G., MD, PhD, Associate Professor, Department

of Traumatology and Orthopedics, Bukovinian State Medical University, Chernivtsi, Ukraine.

Dudko G. Ye., MD, PhD, DSc, Professor, Department

of Traumatology and Orthopedics, Bukovinian State Medical University, Chernivtsi, Ukraine.

Відомості про авторів:

Аудко О. Г., канА. меА. наук, Аоцент каф. травматології та ортопеАії, ВАНЗ “Буковинський Аержавний меАичний університет", м. Чернівці, Україна.

Аудко Г. Є., А-р меА. наук, професор травматології та ортопедії, ВАНЗ "Буковинський Аержавний медичний університет", м. Чернівці, Україна.

Сведения об авторах:

Аудко А. Г., канА. меА. наук, Аоцент каф. травматологии и ортопеАии, ВГУЗ “Буковинский госуАарственный меАицинский университет", г. Черновцы, Украина.

Аудко Г. Е., А-р меА. наук, профессор травматологии и ортопеАии, ВГУЗ “Буковинский государственный медицинский университет", г. Черновцы, Украина.
Надійшка Ао редакції / Received: 21.12.2017

Після Аоопрацювання / Revised: 15.01.2018

Прийнято Ао Аруку / Accepted: 18.01.2018

\section{References}

[1] Haiko, H. V., Kalashnikov A. V., Yukhymchuk O. A., Fedorenko Yu. O., \& Skiba I. A. (2014). Vplyv biomekhanosumisnosti intrameduliarnykh metalevykh fiksatoriv z nyzkomodulnoho $\beta$ (Zr,Ti) splavu na rozvytok reparatyvnoho osteohenezu [Influence of biomechanical compatibility intramedullary metal fixators low modulus of $\beta(\mathrm{Zr}$, Ti) alloy on the development of reparative osteogenesis]. Problemy biomekhaniky ta medychnoho materialoznavstva. Proceedings of the International Scientific and Practical Conference, 1-2(29-30), 82-84. Kyiv. [in Ukrainian].

[2] Reith, G., Schmitz-Greven, V., Hensel, K. O,. Schneider, M. M Tinschmann, T., Bouillon, B., \& Probst, Ch. (2015). Metal implant removal: benefits and drawbacks - a patient survey. BMC Surg, 15, 96. doi: 10.1186/s12893-015-0081-6.

[3] Prakasam, M., Locs, J., Salma-Ancane, K., Loca, D., Largeteau, A., \& Berzina-Cimdina, L. (2017). Biodegradable materials and metallic implants-a review. J. Funct. Biomater, 8(4). pii: E44. doi: 10.3390/ jfb8040044.

[4] Hamad, K., Kaseem, M., Yang, H. W., Deri, F., \& Ko, Y. G. (2015). Properties and medical applications of polylactic acid: A review. EXPRESS Polymer Letters., 9(5), 435-455. doi: 10.3144/expresspolymlett.2015.42.

[5] Yu, X., Zhao, D., Huang, S., Wang, B., Zhang, X., Wang, W., \& Wei, X. (2015). Biodegradable magnesium screws and vascularized iliac grafting for displaced femoral neck fracture in young adults. $B M C$ Musculoskeletal Disorders, 16(1). doi: 10.1186/s12891-015-0790-0.

[6] Chorny, V. N., Yatsun, Ye. V., Golovakha, M. L., \& Shalomeev, V. A (2016). Novyj rastvorimyj splav na osnove magniya dlya primeneniya $v$ travmatologii. [New soluble magnesium-based alloys for use in traumatology]. Ortopediya, travmatologija i protezirovanie, 4(605), 26-33. [in Russian]. doi: 10.15674/0030-59872016426-33. [in Russian].

[7] Dudko, O. G. (2014). Metodyka otsinky rezultativ polimernoho osteosyntezu. [Estimation methodology of polymeric osteosynthesis outcome]. Bukovynskyi medychnyi visnyk, 18, 4(72), 25-28. [in Ukrainian].

[8] Dudko, G. Ye., Drachuk, P. S., Zinchenko, A. T., \& Borodavka, P. S. (1989). Osteosintez konstrukciyami iz poliglikolida [Osteosynthesis using polyglycolide fixation devices]. Ortopediya, travmatologiya $i$ protezirovanie, 11, 13-15. [in Russian]. 